\title{
Impact of Carbon Nanomaterials on the Antioxidant System of Tomato Seedlings
}

\author{
Yolanda González-García ${ }^{1}$, Elsy Rubisela López-Vargas ${ }^{1}$, Gregorio Cadenas-Pliego ${ }^{2}$ (D), \\ Adalberto Benavides-Mendoza ${ }^{3}$, Susana González-Morales ${ }^{4}{ }^{\mathbb{D}}$, Armando Robledo-Olivo ${ }^{5} \mathbb{(}$, \\ Ángel Gabriel Alpuche-Solís ${ }^{6}$ and Antonio Juárez-Maldonado $7, *$ (i)
}

1 Doctorado en Ciencias en Agricultura Protegida, Universidad Autónoma Agraria Antonio Narro, Saltillo, Coahuila 25315, Mexico; yolanda_glezg@hotmail.com (Y.G.-G.); lopez2690vargas@gmail.com (E.R.L.-V.)

2 Centro de Investigación en Química Aplicada, Saltillo, Coahuila 25294, Mexico; gregorio.cadenas@ciqa.edu.mx

3 Departamento de Horticultura, Universidad Autónoma Agraria Antonio Narro, Saltillo, Coahuila 25315, Mexico; adalberto.benavides@uaaan.edu.mx

4 CONACyT- Departamento de Horticultura, Universidad Autónoma Agraria Antonio Narro, Saltillo, Coahuila 25315, Mexico; qfb_sgm@hotmail.com

5 Departamento de Alimentos, Universidad Autónoma Agraria Antonio Narro, Saltillo, Coahuila 25315, Mexico; armando.robledo@uaaan.edu.mx

6 Instituto Potosino de Investigación Científica y Tecnológica, San Luis Potosí, San Luis Potosí 78216, Mexico; alpuche@ipicyt.edu.mx

7 Departamento de Botánica, Universidad Autónoma Agraria Antonio Narro, Saltillo, Coahuila 25315, Mexico

* Correspondence: antonio.juarez@uaaan.edu.mx or juma841025@hotmail.com; Tel.: 52-844-411-0317

Received: 4 October 2019; Accepted: 20 November 2019; Published: 22 November 2019

check for updates

\begin{abstract}
Tomato is one of the most economically important vegetables worldwide and is constantly threatened by various biotic and abiotic stress factors reducing the quality and quantity in the production of this crop. As an alternative to mitigate stress in plants, carbon nanomaterials (CNMs) have been used in agricultural areas. Therefore, the objective of the present work was to evaluate the antioxidant responses of tomato seedlings to the application via foliar and drench of carbon nanotubes (CNTs) and graphene (GP). Different doses (10, 50, 100, 250, 500, and $1000 \mathrm{mg} \mathrm{L}^{-1}$ ) and a control were evaluated. The results showed that the fresh and dry root weight increased with the application of CNMs. Regarding the antioxidant responses of tomato seedlings, the application of CNMs increased the content of phenols, flavonoids, ascorbic acid, glutathione, photosynthetic pigments, activity of the enzyme's ascorbate peroxidase, glutathione peroxidase, catalase, and phenylalanine ammonia lyase as well as the content of proteins. Therefore, the use of carbon-based nanomaterials could be a good alternative to induce tolerance to different stress in tomato crop.
\end{abstract}

Keywords: carbon nanotubes; graphene; antioxidant compounds; enzymatic activity; oxidative stress

\section{Introduction}

Advances in nanotechnology have provided new materials with various applications. Proof of this are the so-called carbon nanomaterials (CNMs) that have been used in various areas including agriculture [1]. These CNMs have the characteristic that they can be easily absorbed by plant cells causing positive impacts on plant growth and development [2]. Among the application highlights are the high potential for the elimination of pesticides in water [3], ability to remove heavy metals from soil and water [4], and antifungal and bactericidal effects. In agriculture, they have been applied to stimulate seed germination [1], and they also act as growth regulators [5] and stimulate the antioxidant activity of plants [2]. 
Among the most studied CNMs in agriculture are graphene, carbon nanotubes, graphite, and fullerene [5]. Graphene (GP) is a nanostructure composed of a single layer of carbon atoms densely packed in a benzene ring structure [6] with thermodynamically favorable configurations of $\mathrm{sp}^{3}$ to $\mathrm{sp}^{2}$, depending on the heat of the formation and the pressure conditions [7]. It has a carbon-carbon bond length of approximately $0.142 \mathrm{~nm}$ and the diameter of the graphene layer is approximately $0.35 \mathrm{~nm}$ [8]. This gives it unique properties such as a two-dimensional flat structure, large surface area, chemical and mechanical stability, excellent conductivity, good biocompatibility, and ease of functionalization $[9,10]$. On the other hand, carbon nanotubes (CNTs) are rolled laminar structures of hybridized carbon atoms $\left(\mathrm{sp}^{2}\right)$ arranged hexagonally, forming hollow cylindrical tubes [11]. Its dimensions are a few nanometers in diameter (up to approximately $100 \mathrm{~nm}$ ) and lengths in the micrometer range [12]. Depending on the number of graphene layers, they are classified as single-walled CNTs (SWCNTs) or multiple-walled CNTs (MWCNTs) [12]. Carbon nanotubes are well assembled and have a good surface area, high strength, and excellent chemical and thermal properties [11]. It has been shown that both graphene and carbon nanotubes are biocompatible materials [9,13]; thus, they can be applied in plants.

It is well known that the toxicity of CNMs depends mainly on the dose applied, although the exposure time and the plant species used also has an influence [14]. It has been shown that doses of $500-2000 \mathrm{mg} \mathrm{L}^{-1}$ of graphene in a nutritive solution for 20 days inhibits growth and increases the concentration of reactive oxygen species (ROS) in seedlings of cabbage (Brassica oleracea), tomato (Solanum lycopersicum), and red spinach (Spinacia oleracea); however, no toxic effect on the seedlings of lettuce (Lactuca sativa) was observed [15]. In the case of CNTs, a dose of $1000-2000 \mathrm{~m} \mathrm{~L}^{-1}$ in nutritive solution for 15 days affected root growth and shoots in red spinach (S. oleracea), lettuce (L. sativa), and cucumber (Cucumis sativus) but had no toxic effect on chili pepper (Capsicum annuum), lady's finger (Sedum pachyphyllum), and soybeans (Glycine max) [16]. In seedlings of Hyoscyamus niger treated with CNTs at concentrations of 400 and $800 \mathrm{mg} \mathrm{L}^{-1}$, a decrease in germination and yield was observed; however, at low doses (50 and $\left.100 \mathrm{mg} \mathrm{L}^{-1}\right)$, they presented the opposite effect, since the germination and vigor of the plants increased [17].

In addition to its economic relevance, tomato has been identified as a food of great interest due to the fact of its high content of bioactive compounds [18]. Tomato, like all crop plants, are subject to various types of stress, both biotic and abiotic [19]. Therefore, the application of nanomaterials as biostimulants is interesting [20] as an alternative to increase the yield, quality, productivity, and defense of plants [21]. However, to achieve this, an understanding of how CNMs act is required; thus, the present research aimed to evaluate the antioxidant responses and growth of tomato seedlings treated with $\mathrm{CNMs}$ - carbon nanotubes and graphene-through two routes of application.

\section{Results}

\subsection{Crop Growth}

The results obtained showed that when the CNMs were applied via foliar, there was no impact on the shoot and root biomasses, indicating that there was no toxicity due to the presence of any of the doses used (Figure 1). When the application was done via drench, only significant differences were observed among treatments in the root biomass. In the fresh root biomass, there were no differences compared with the control. While in the dry root biomass, $100 \mathrm{mg} \mathrm{L}^{-1}$ of CNT was the best treatment with $87 \%$ more biomass than the control. Also $250 \mathrm{mg} \mathrm{L}^{-1}$ of CNT and $10 \mathrm{mg} \mathrm{L}^{-1}$ of GP generated more root biomass than the control by $47 \%$. 

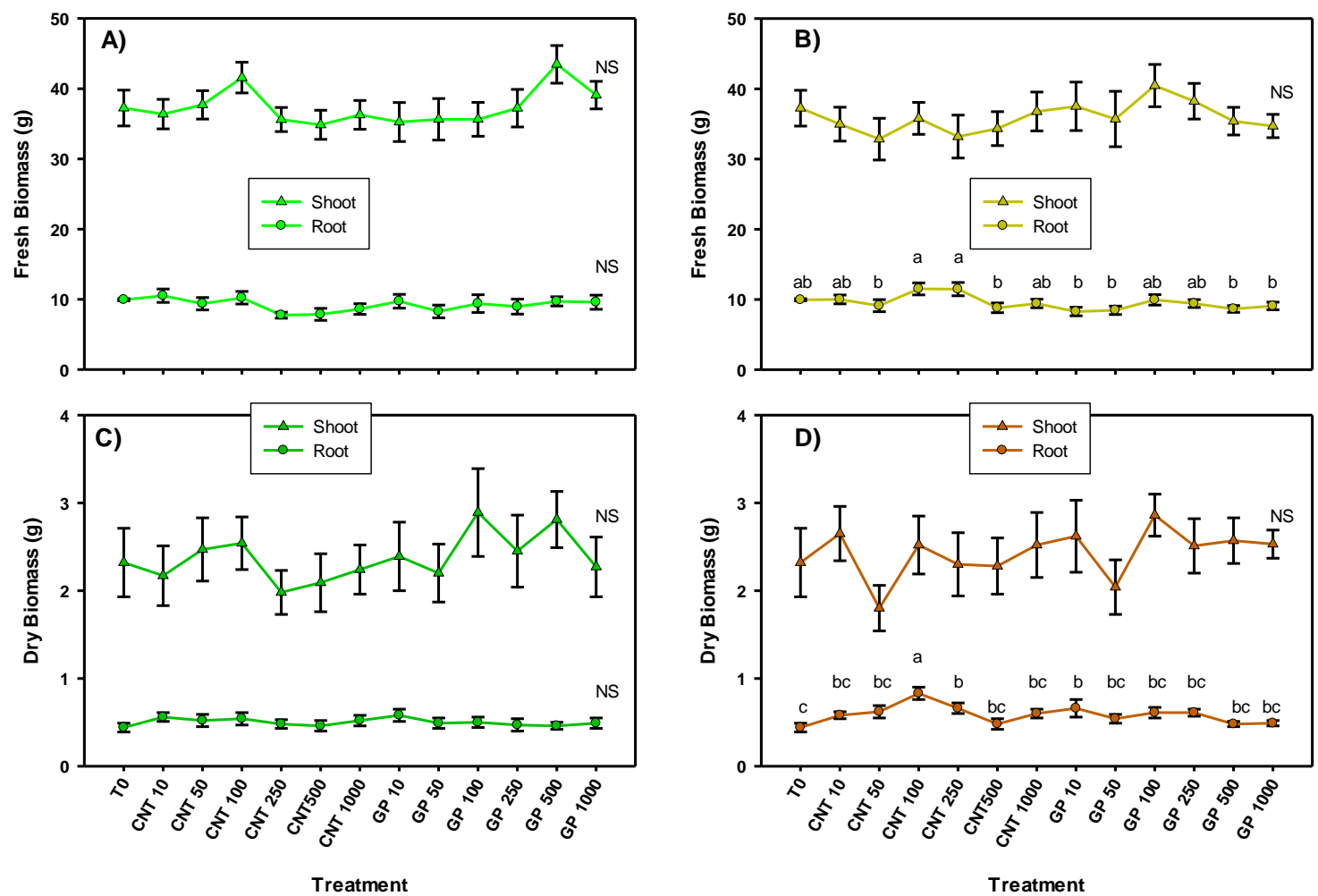

Figure 1. Shoot and root biomass of tomato seedlings with carbon nanomaterials applied via foliar $(\mathbf{A}, \mathbf{C})$ and drench (B,D). T0: control; CNTs: carbon nanotubes; GP: graphene; DW: dry weight; 10, 50, 100,250 , and 500 represent the $\mathrm{mg} \mathrm{L}^{-1}$ applied of each carbon nanomaterial. Different letters indicate significant differences among treatments according to Duncan $(\alpha=0.05) . n=5 \pm$ standard error.

\subsection{Photosynthetic Pigments}

The chlorophyll content in the leaves of tomato seedlings treated with graphene and carbon nanotubes showed significant differences among treatments (Figure 2). The results were consistent between both routes of application, since all treatments applied to CNTs and GP increased the chlorophyll a content. The application of GP at $500 \mathrm{mg} \mathrm{L}^{-1}$ induced the best response being $66 \%$ more than the control in the foliar application and $72 \%$ more in the application via drench. In addition, there was a clear trend that treatments with graphene application induced a higher chlorophyll content compared to the application of CNTs, regardless of the route of application. Derived from the increase observed in chlorophyll a, an increase in total chlorophyll was also observed. On the other hand, chlorophyll $\mathrm{b}$ increased with the application of graphene via drench at 10,50 , and $100 \mathrm{mg} \mathrm{L}^{-1}$ by $23 \%$, $39 \%$, and $21 \%$, respectively, compared to the control. In foliar application, only the $10 \mathrm{mg} \mathrm{L}^{-1}$ of CNT treatment showed an increase in chlorophyll b by $25 \%$ compared to the control.

\subsection{Non-Enzymatic Antioxidant Compounds}

The application of CNMs modified the content of the non-enzymatic antioxidant compounds (glutathione, vitamin C, phenols, and flavonoids), generally in a positive way (Figure 3). The glutathione content presented the greatest increase with the application of CNTs at $10 \mathrm{mg} \mathrm{L}^{-1}$, both in foliar application $(42.94 \%)$ and in drench application $(65.49 \%)$. However, when graphene was applied, the behavior was different depending on the route of application. By foliar route, the doses of 50, 100, and $250 \mathrm{mg} \mathrm{L}^{-1}$ increased the glutathione content compared to the control by $25.7 \%, 24.7 \%$, and $22 \%$, respectively; while in the application via drench, only the dose of $1000 \mathrm{mg} \mathrm{L}^{-1}$ induced an increase $(26.47 \%)$ compared with the control. 

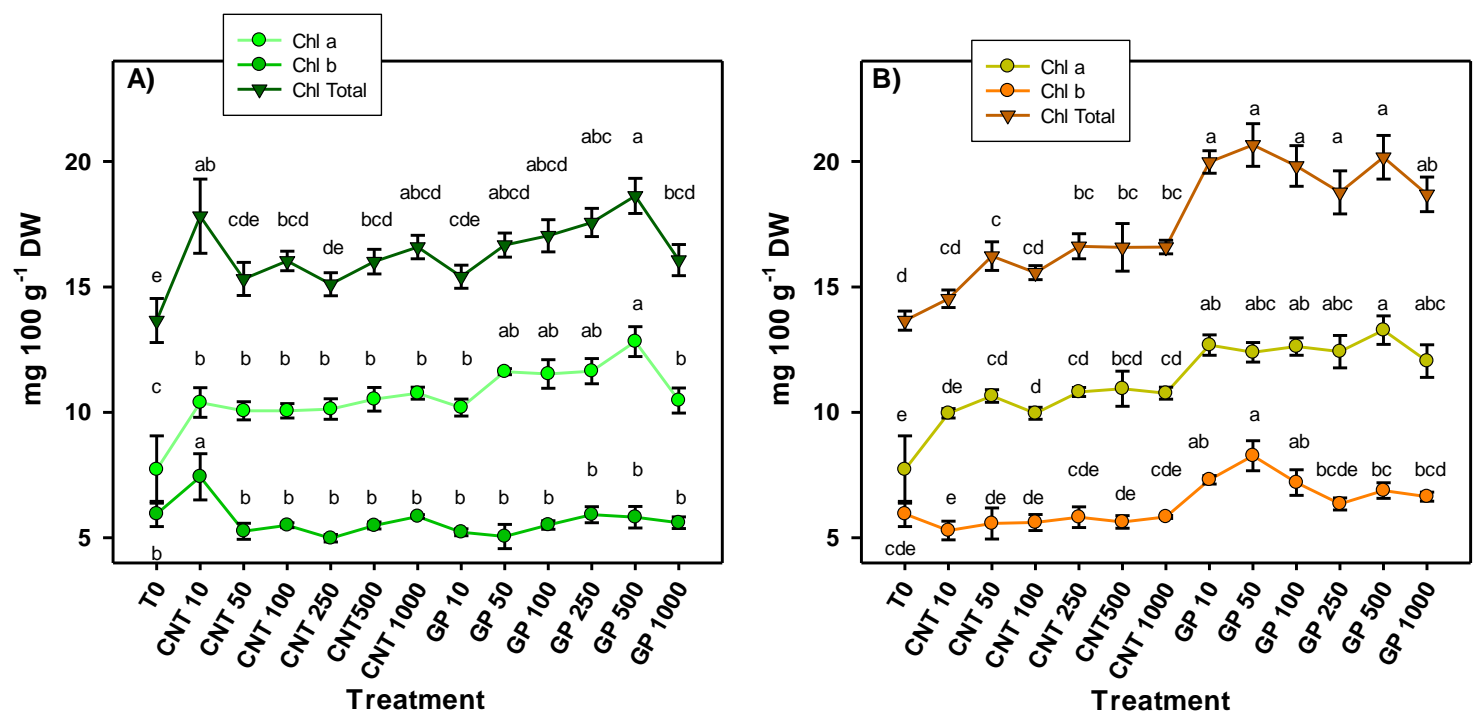

Figure 2. Photosynthetic pigments in tomato seedlings treated with carbon nanomaterials applied via foliar (A) and drench (B). Chl a: chlorophyll a; Chl b: chlorophyll b; Chl Total: sum of chlorophyll a + chlorophyll b; T0: control; CNTs: carbon nanotubes; GP: graphene; DW: dry weight; 10, 50, 100, 250, and 500 represent the $\mathrm{mg} \mathrm{L}^{-1}$ applied of each carbon nanomaterial. Different letters indicate significant differences among treatments according to Duncan $(\alpha=0.05) . n=5 \pm$ standard error.

The ascorbic acid content was positively modified by the application of CNMs regardless of the route of application, especially with CNTs (Figure 3). The doses of 10, 50, and $100 \mathrm{mg} \mathrm{L}^{-1}$ of CNT generated the highest content of this compound in foliar application, up to $59 \%, 63 \%$, and $57 \%$, respectively, compared with the control. When applied via drench, doses of 10, 50,100, and $500 \mathrm{mg} \mathrm{L}^{-1}$ of CNT induced an increase in ascorbic acid compared with the control by $118 \%, 120 \%, 70 \%$, and $59 \%$, respectively. These results indicate that the application of CNTs via drench induced a better response in the content of ascorbic acid compared to the application via foliar. In contrast, the application of graphene via foliar induced a better response than when applied via drench. Doses of $500 \mathrm{mg} \mathrm{L}^{-1}$ followed by $1000 \mathrm{mg} \mathrm{L}^{-1}$ applied via foliar induced the highest concentration compared to the control ( $55 \%$ and $46 \%$ more, respectively), while, via drench, only the graphene at $50 \mathrm{mg} \mathrm{L}^{-1}$ induced a positive response compared with the control (31.8\%).

The phenols content consistently increased with the application of both CNTs and graphene for both routes of application (Figure 3). Likewise, it was observed that graphene induced better responses than CNTs, mainly the doses of 100 and $500 \mathrm{mg} \mathrm{L}^{-1}$ of GP. When applied by foliar route, both doses of GP increased the phenols content by $68 \%$ compared with the control, and, when they were applied via drench, there was an increase of $74 \%$ with $100 \mathrm{mg} \mathrm{L}^{-1}$ and $54 \%$ with $500 \mathrm{mg} \mathrm{L}^{-1}$.

In the case of flavonoids, the best response was observed when the application was done via drench and especially with graphene (Figure 3). The application of $100 \mathrm{mg} \mathrm{L}^{-1}$ of graphene via drench induced the greatest number of flavonoids, $28.6 \%$ more than the control; although, the doses of 10, 50, 250 and $1000 \mathrm{mg} \mathrm{L}^{-1}$ were also better than the control. As for the CNTs applied via drench, the dose of $50 \mathrm{mg} \mathrm{L}^{-1}$ showed an increase of $17.3 \%$; in addition, the doses of 250 and $500 \mathrm{mg} \mathrm{L}^{-1}$ also showed an increase of $9.3 \%$ and $11.9 \%$, respectively, compared with the control. When the application was done via foliar, the doses of 500 and $250 \mathrm{mg} \mathrm{L}^{-1}$ of graphene induced the greater accumulation of flavonoids, being $14 \%$ and $10 \%$ more than the control, respectively. In the case of the CNTs applied via foliar, an increase of $11.8 \%$ and $7.7 \%$ was observed with the doses of 100 and $10 \mathrm{mg} \mathrm{L}^{-1}$, respectively.

The antioxidant capacity determined by the DPPH (2,2-diphenyl-1-picrylhydrazyl) radical was consistent for both routes of application, since, in both cases, the treatment of CNT at $100 \mathrm{mg} \mathrm{L}^{-1}$ generated the best response, increasing by $53.5 \%$ in foliar application and $56.8 \%$ in application via drench compared with the control (Figure 4). Also, doses of 10 and $50 \mathrm{mg} \mathrm{L}^{-1}$ induced a favorable 
response in antioxidant capacity. As for graphene, the highest dose $\left(1000 \mathrm{mg} \mathrm{L}^{-1}\right)$ was the one that induced the best result in antioxidant capacity for both routes of application; however, only in the drench route application was there a significant difference compared to the control ( $40 \%$ more).
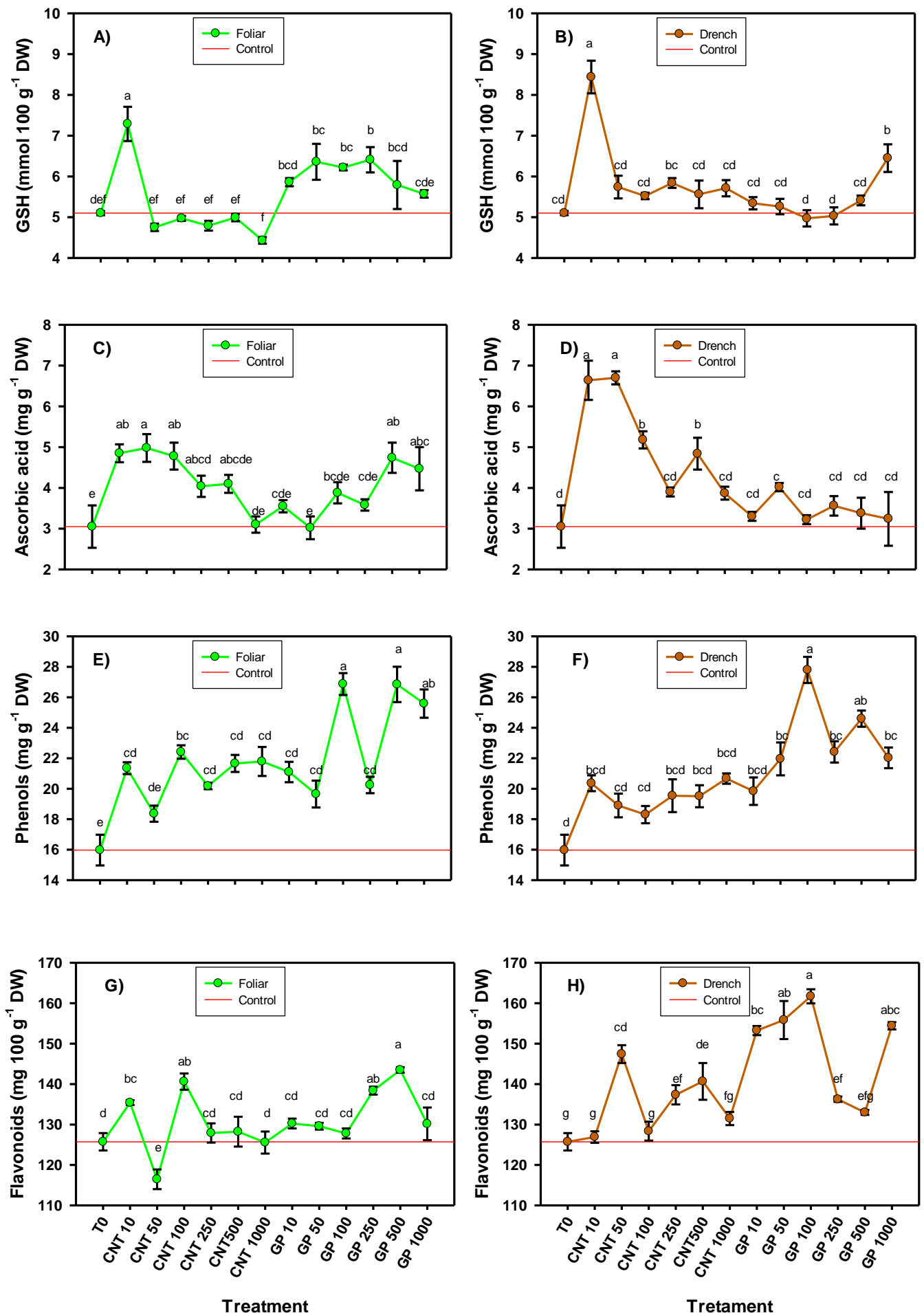

Figure 3. Glutathione (A,B), ascorbic acid (C,D), phenols (E,F), and flavonoids $(\mathbf{G}, \mathbf{H})$ in tomato seedlings with the application of carbon nanomaterials. T0: control; CNTs: carbon nanotubes; GP: graphene; DW: dry weight; 10, 50, 100, 250, and 500 represent the $\mathrm{mg} \mathrm{L}^{-1}$ applied of each carbon nanomaterial. Different letters indicate significant differences among treatments according to Duncan $(\alpha=0.05)$. $n=5 \pm$ standard error. 


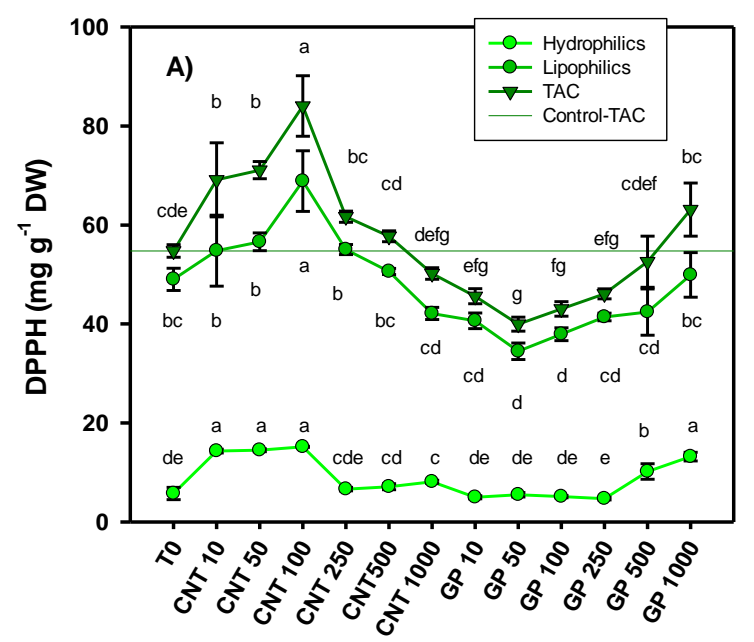

Treatment

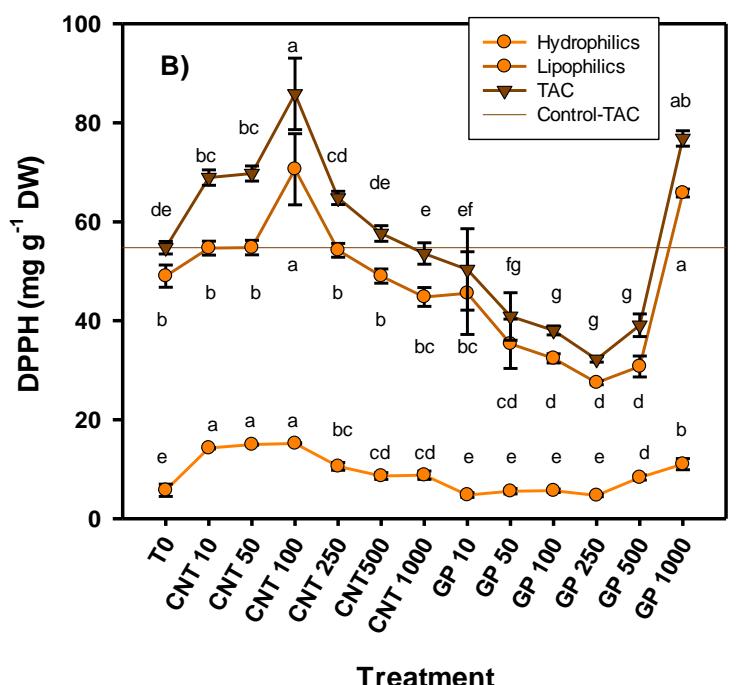

Treatment

Figure 4. Antioxidant capacity in tomato seedlings treated with carbon nanomaterials applied via foliar (A) and drench (B). TAC: total antioxidant capacity. T0: control; CNTs: carbon nanotubes; GP: graphene; DW: dry weight; 10, 50, 100, 250, and 500 represent the $\mathrm{mg} \mathrm{L}^{-1}$ applied of each carbon nanomaterial. Different letters indicate significant differences among treatments according to Duncan $(\alpha=0.05) . n=5 \pm$ standard error.

\subsection{Protein Content and Enzymatic Activity}

The protein content was positively affected by the application of CNMs. In both routes of application, very similar results were observed, where graphene was the one that induced the best response (Figure 5). When CNTs were applied, only the lowest dose $\left(10 \mathrm{mg} \mathrm{L}^{-1}\right)$ induced an increase compared to the control in both the foliar (19.4\%) and the drench routes $(13.7 \%)$. When graphene was applied, virtually all doses applied induced higher protein content. In the foliar application, $10 \mathrm{mg} \mathrm{L}^{-1}$ of graphene induced the greatest amount of proteins, $19.4 \%$ more than the control, while in application via drench, $50 \mathrm{mg} \mathrm{L}^{-1}$ graphene induced $17.8 \%$ more proteins than the control.

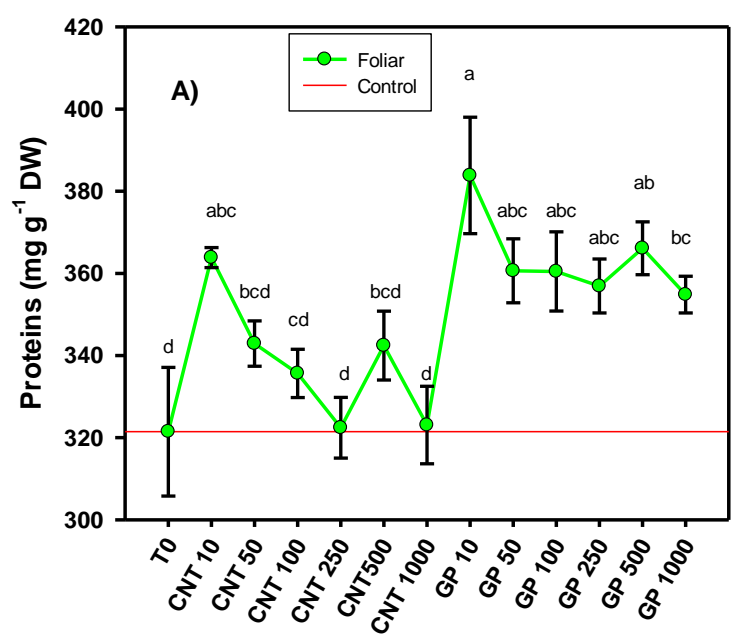

Treatment

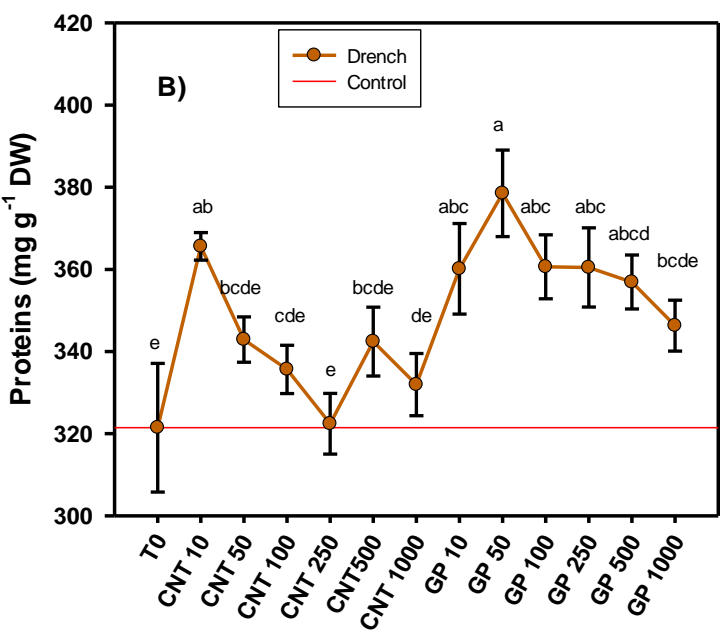

Treatment

Figure 5. Protein content in tomato seedlings treated with an application of carbon nanomaterials applied via foliar (A) and drench (B). T0: control; CNTs: carbon nanotubes; GP: graphene; DW: dry weight; 10, 50, 100, 250, and 500 represent the $\mathrm{mg} \mathrm{L}^{-1}$ applied of each carbon nanomaterial. Different letters indicate significant differences among treatments according to Duncan $(\alpha=0.05)$. $n=5 \pm$ standard error. 
The activity of all the enzymes evaluated was modified by the application of the CNMs, although some enzymes also presented a different response depending on the route of application (Figure 6). Foliar application of all CNT doses induced a greater activity of the APX enzyme compared with the control (119-196\%), while, with graphene, only the doses of 10, 100, and $250 \mathrm{mg} \mathrm{L}^{-1}$ induced greater APX activity in comparison with the control in a range of $107-150 \%$. When the application was via drench, doses of 10, 50, 100, and $250 \mathrm{mg} \mathrm{L}^{-1}$ of CNT increased APX activity compared to the control in a range of $129-177 \%$; while graphene at $1000 \mathrm{mg} \mathrm{L}^{-1}$ increased APX activity by $175 \%$, followed by $10 \mathrm{mg} \mathrm{L}^{-1}$ with an increase of $129 \%$.

The GPX activity presented very different results when the CNMs were applied via foliar or via drench (Figure 6). In foliar application, only the $1000 \mathrm{mg} \mathrm{L}^{-1}$ dose of CNT induced an increase in GPX activity, 39.6\% more than the control. In application via drench, all CNMs treatments increased GPX activity, especially with the application of graphene. The CNT increased the activity of GPX in a range of 50-70\% compared to the control, while graphene treatments induced an increase in a range of $57-127 \%$ with the dose of $50 \mathrm{mg} \mathrm{L}^{-1}$ which generated the best response.

The catalase activity presented different changes according to the route of application of the CNMs (Figure 6). In foliar application, $50 \mathrm{mg} \mathrm{L}^{-1}$ of CNT was the only treatment that induced greater activity of this enzyme with an increase of $81 \%$ compared with the control. In application via drench, doses of 1000 and $500 \mathrm{mg} \mathrm{L}^{-1}$ of graphene induced an increase of $135 \%$ and $111 \%$, respectively.

The activity of the phenylalanine ammonia lyase (PAL) enzyme was also affected differently depending on the route of application of the CNMs, since, in foliar application, with the exception of one treatment, the rest induced greater activity compared with the control, while via drench, only the application of $10 \mathrm{mg} \mathrm{L}^{-1}$ of CNT induced an increase of $40 \%$ compared with the control. In the foliar application, differences were also observed among the types of CNMs used, since the application of CNTs generated a better response than graphene in PAL activity. Doses of 100, 250, and $500 \mathrm{mg} \mathrm{L}^{-1}$ induced the greatest increase in PAL activity, $254 \%, 267 \%$, and $281 \%$ more than the control, respectively. With graphene, the best result was obtained with 500 and $250 \mathrm{mg} \mathrm{L}^{-1}$ which increased the PAL activity up to $146 \%$ and $121 \%$, respectively, compared with the control.
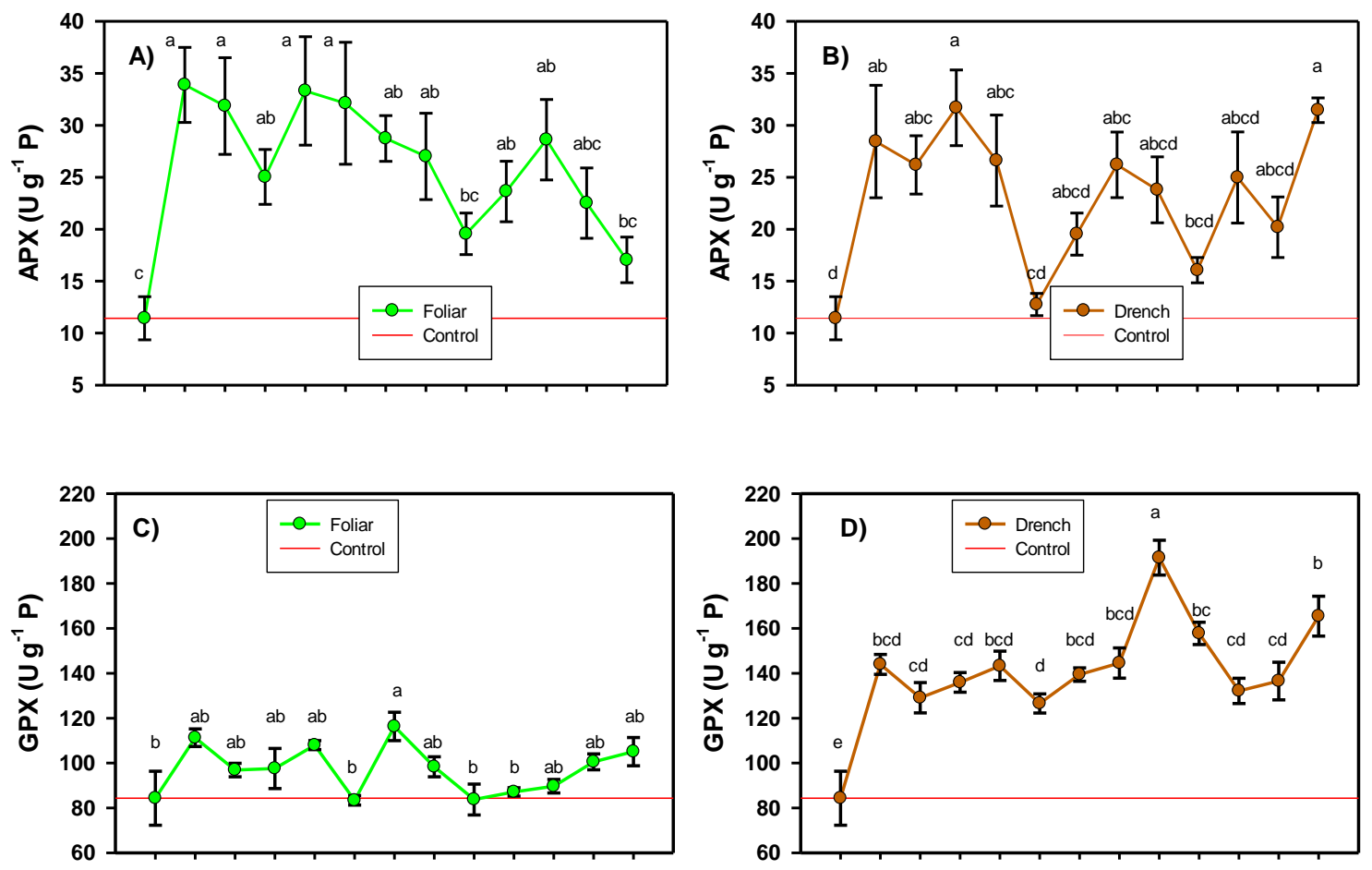

Figure 6. Cont. 

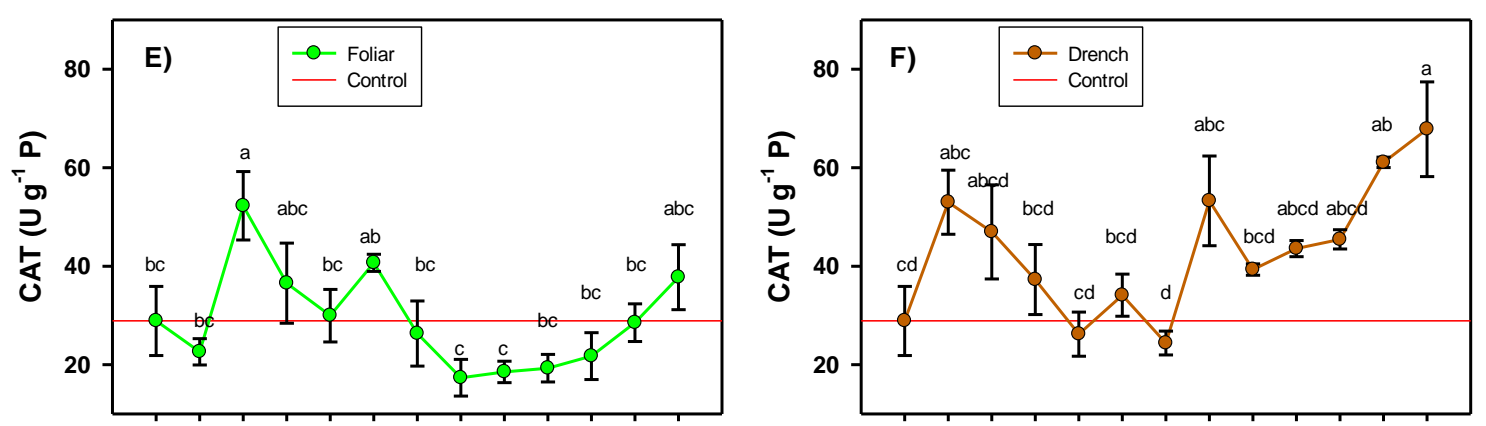

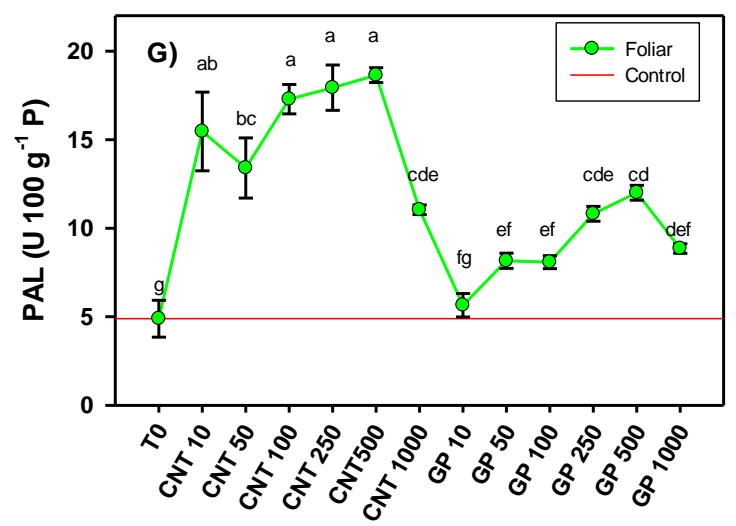

Treatment

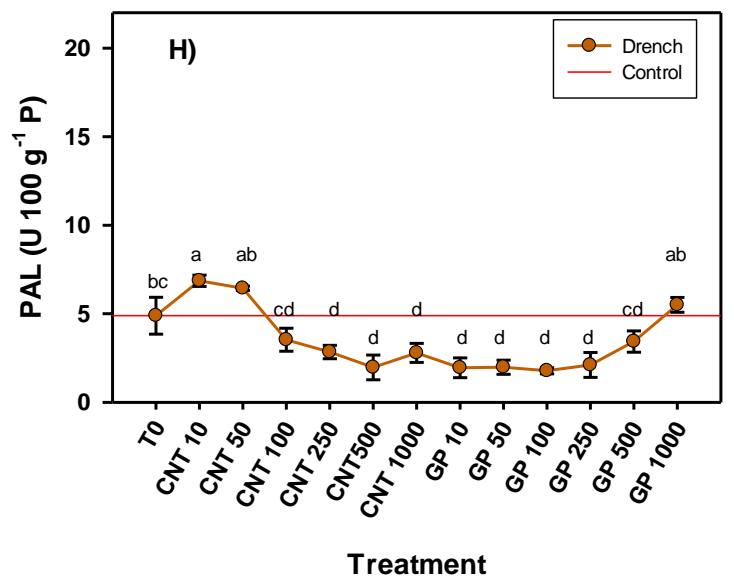

Figure 6. Enzymatic activity (ascorbate peroxidase (A,B), glutathione peroxidase (C,D), catalase (E,F), and phenylalanine ammonia lyase $(\mathbf{G}, \mathbf{H})$ in tomato seedlings treated with carbon nanomaterials applied via foliar and drench. T0: control; CNTs: carbon nanotubes; GP: graphene; P: proteins; 10, 50, 100, 250, and 500 represent the $\mathrm{mg} \mathrm{L}^{-1}$ applied of each carbon nanomaterial. Different letters indicate significant differences among treatments according to Duncan $(\alpha=0.05) . n=5 \pm$ standard error.

\section{Discussion}

The increase in root biomass may be related to the fact that CNMs have the ability to bind and penetrate the root surface which improves the capillary action of water and nutrient absorption [22]. In addition, they act as elicitors in the regulation of plant growth [5], since they activate the biosynthesis of indole acetic acid and abscisic acid [23]. They also promote the expression of marker genes of cell division $(C y c B)$ and elongation of the cell wall (NtLRX1) [24] that directly influence growth. Additionally, they increase the activity of the enzymes superoxide dismutase (SOD), guaiacol peroxidase (POD), catalase (CAT), and ascorbate peroxidase (APX), resulting in the accumulation of proteins in the roots [25] which can increase disease resistance [5] and, ultimately, contribute to healthier and more vigorous roots. Similar results have been reported by various authors. Tripathi et al. [22] demonstrated a significant increase in the growth rate of chickpea (Cicer arietinum) plant roots with the application of CNTs to $100 \mathrm{mg} \mathrm{L}^{-1}$ in seeds. Joshi et al. [26] reported an increase in the number and length of radicle in wheat (Triticum aestivum) plants with CNT application. In contrast, Begum et al. [15], reported that the application of graphene in doses of 500, 1000, and $2000 \mathrm{mg} \mathrm{L}^{-1}$ significantly affected the size and weight of the roots in cabbage (Brassica oleracea), tomato (Solanum lycopersicum), and red spinach (Spinacia oleracea) crops. This indicates that the responses may be different depending on the type of CNMs used, the dose applied as well as the route of application.

As an essential cofactor of photosystem I and II, chlorophylls play a fundamental role in photosynthesis, since they are responsible for both the absorption of visible light and its photochemical conversion within the cell [27]. Chlorophyll $a$ is in a higher concentration than chlorophyll $b$, 
commonly 3:1 [28], so chlorophyll a is more susceptible to being affected by environmental factors as CNMs. Both carbon nanotubes and graphene have the ability to penetrate the cells of the epidermis and transport via endocytosis to cell walls, mitochondria, and chloroplasts [29]. In spinach plants (S. oleracea), the application of carbon nanotubes increased electron flow and photosynthetic activity due to the stimulating action on light absorption caused by the penetration of CNTs into chloroplast membranes [30]. Likewise, Giraldo et al. [31] showed that the application of carbon nanomaterials in S. oleracea increased the number and size of chloroplasts, and, as a result, there was an increase in chlorophylls and photosynthetic activity. Begum et al. [16] reported an increase in chlorophyll a and b content with the addition of carbon nanotubes in a wild carrot crop (Daucus carota). Siddiqui et al. [32] also reported an increase in carrot chlorophyll content with the application of graphene oxide at $10 \mathrm{mg}$ $\mathrm{L}^{-1}$. The results obtained in this work are consistent with those reported in the literature which shows that the application of CNMs induces favorable responses in plant photosynthetic pigments which can potentially increase photosynthetic capacity.

The antioxidant defense system of plants works from a set of enzymatic (APX, GPX, CAT, SOD, etc.) and non-enzymatic (glutathione, ascorbic acid, phenols, etc.) antioxidant compounds which participate directly or indirectly in the control of reactive oxygen species. Glutathione (GSH) is a molecule composed of three amino acids, L-cysteine, L-glutamic acid, and glycine, and acts as an antioxidant [33]. In plants, GSH plays a very important role, since together with ascorbic acid it is part of the ascorbate-glutathione cycle [34]. In addition, it improves osmoregulation, the efficiency of water and nutrient use, and photosynthetic performance [35]. On the other hand, ascorbic acid is a metabolite of great importance, since it acts in the antioxidant defense system of plants and is a key substrate for detoxification and stable maintenance of reactive oxygen species (ROS) within chloroplasts, peroxisomes, mitochondria, and cell cytosol [36].

Phenolic compounds are a chemically diverse group of secondary metabolites that occur ubiquitously in plants [37]. They can be divided into several groups, including phenolic acids, flavonoids, stilbenes, and lignans, depending on their chemical structure [38]. They commonly act as chemical and physical barriers to protect plants against biotic and abiotic stress [39], provide protection against excess sunlight by absorbing high energy wavelengths [40], and they can also protect plants from various pests and diseases [41].

According to the results obtained in this work, as well as those reported in the literature, CNMs can modify the antioxidant defense system of plants through the increase of antioxidant compounds. This is because CNMs can induce slight oxidative stress in plants [16] and overexpress the genes involved in stress signaling in plants [2]. This results in the production of antioxidant compounds, such as phenolic acids and flavonoids [2], ascorbic acid [16], polyphenolic compounds [42], and others, which ultimately decrease oxidative stress and improve defense against other types of biotic or abiotic stress. However, the observed responses depend on the concentration of CNMs applied, since a hormetic response can be observed where low concentrations can induce positive effects but high concentrations induce the opposite effect, and, in addition to higher concentrations, a positive effect can be observed again. This hormetic effect is commonly observed in plants, since it is a dynamic adaptive response of complex biological systems to different stressors [43].

Antioxidant enzymes are part of the antioxidant defense system of plants and, in turn, are considered proteins. It is known that the application of CNMs, such as carbon nanotubes, have the ability to induce the production of antioxidant enzymes which results in an accumulation of proteins [25]. In addition, it has been reported that the application of nanomaterials can increase the content of aquaporins, a type of protein specializing in the transport of water located in the membranes [44]. An increase in the proline amino acid has been reported in carrot plants when graphene oxide was applied at $0.10 \mathrm{mg} \mathrm{L}^{-1}$ [32]. This is consistent with what was observed in the present study, since it was demonstrated that both CNTs and graphene induce a greater accumulation of proteins in tomato seedlings. 
Antioxidant enzymes play a very important role in plants, as they protect cells from alterations induced by oxidative stress, because they neutralize reactive oxygen species [42]. Although CNMs can induce oxidative stress in plant cells [45], due to the ability they have to translocate to the different organelles of the cells [7], the result is beneficial for the plant, since it induces the generation of free radicals [46] which leads to the activation of enzymes to mitigate oxidative stress. Among these enzymes is APX which helps decrease the oxidative state of chloroplasts due to the neutralization and balance of ROS [36]. Both GPX and CAT are other major enzymes responsible for the elimination of $\mathrm{ROS}$ and catalyze the reduction of $\mathrm{H}_{2} \mathrm{O}_{2}$ to prevent cell damage [47]. The results of this work showed that the activity of different antioxidant enzymes in tomato seedlings increased due to the application of CNMs which is consistent with that reported by various authors. In a crop of beans (Phaseolus vulgaris), the application of graphene oxide (400 and $\left.800 \mathrm{mg} \mathrm{L}^{-1}\right)$ increased the activity of APX and CAT; however, at a higher dose $\left(1600 \mathrm{mg} \mathrm{L}^{-1}\right)$, it generated the opposite effect [48]. Rong et al. [25] showed that the application of multi-walled carbon nanotubes $\left(2.5,5\right.$, and $\left.10 \mathrm{mg} \mathrm{L}^{-1}\right)$ increased the activity of APX and CAT in a crop of beans (P. vulgaris) under heavy metal stress.

The PAL enzyme, although it does not have an antioxidant function directly, is important in the antioxidant defense system due to the fact of its participation in the phenylpropanoid pathway [49]. These are precursors of phenolic compounds that give the plant greater antioxidant capacity, in addition to increasing defense against pathogens, improving tolerance against biotic stress [50]. This enzyme was also stimulated by the application of CNMs, especially foliar pathways, so it can be expected that this type of nanomaterial will confer greater tolerance against pathogens to tomato seedlings.

\section{Materials and Methods}

\subsection{Crop Growth}

Tomato seeds of the variety "Pony" (Harris Moran, Davis, CA, USA) of saladette type and determined growth were used. Direct sowing was carried out, placing a tomato seed in a $1 \mathrm{~L}$ polystyrene container. Ten repetitions were used per treatment, considering one seedling as an experimental unit. A mixture of peat moss, perlite in a 1:1 ratio, was used as a substrate. For the seedling nutrition, Steiner solution was applied [51]. The crop was developed for 60 days from sowing.

\subsection{Characteristics of Carbon Nanomaterials and Treatments}

Two types of carbon nanomaterials were used: carbon nanotubes and graphene. The carbon nanotubes (CNTs) were multilayer with a diameter of 30-50 nm, length of 10 to $20 \mu \mathrm{m}$, and a purity of approximately 95\% (Nanostructured \& Amorphous Materials, Inc., Houston, TX, USA) (Figure 7A). The graphene (GP) used was multilayer with a diameter of $2 \mu \mathrm{m}$, a thickness of 8 to $12 \mathrm{~nm}$, and a purity of $97 \%$ (Cheap Tubes Inc., Cambridgeport, VT, USA) (Figure 7B). The dispersion of the CNMs was determined through the Z potential, using a Z potential analyzer (ZetaCheck, ZC 0006, Microtrac, Montgomery, PA, USA), being $-39.1 \mathrm{mV}$ for the CNTs and $-35.2 \mathrm{mV}$ for the GR.

The treatments consisted of the use of CNTs and GP in different doses $(10,50,100,250,500$, and $1000 \mathrm{mg} \mathrm{L}^{-1}$ ) and applied via foliar or drench, plus a control. The treatments were applied only once, 45 days after sowing (dds), applying $1.5 \mathrm{~mL}$ of each solution for each seedling. In the case of the control, only distilled water was applied.

\subsection{Sampling}

After $60 \mathrm{dds}$, samples of the third fully developed young leaf were taken to perform the biochemical analyses. The fresh shoot and root biomass were quantified and dry shoot and root biomass were obtained after drying for 48 hours at $80{ }^{\circ} \mathrm{C}$. 

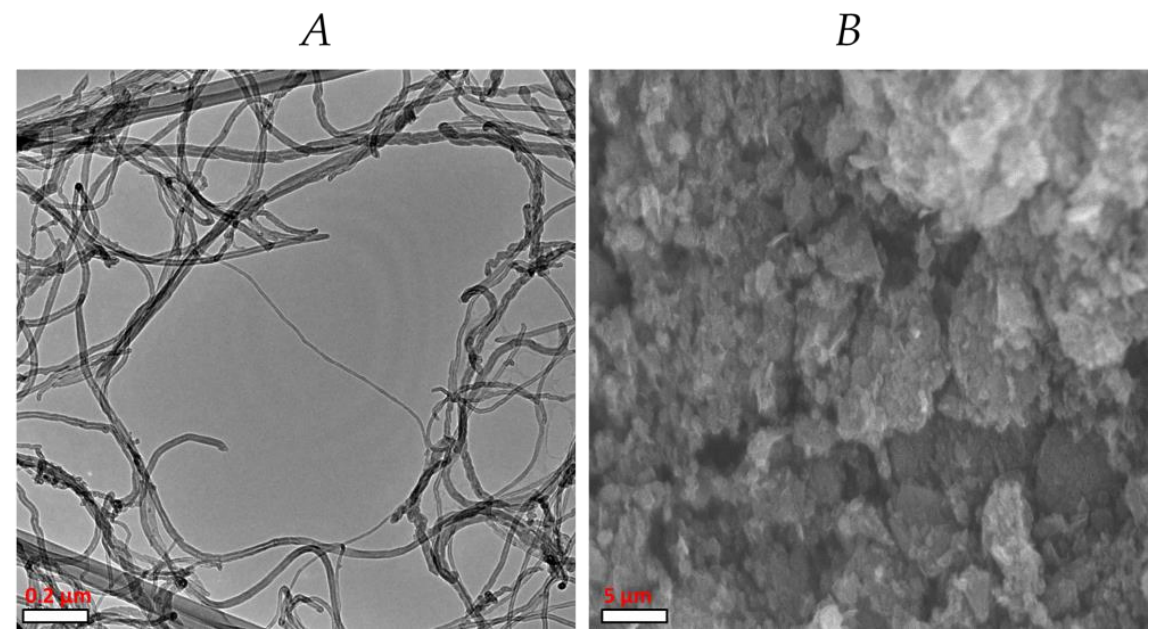

Figure 7. Carbon nanotubes (A) and graphene (B) obtained by scanning electron microscopy.

\subsection{Biochemical Analysis}

The content of chlorophyll was determined according to the method of Nagata and Yamashita [52]. The absorbances at 645 and $663 \mathrm{~nm}$ were determined and used in Equations (1) and (2) to determine the content of chlorophyll, as follows:

$$
\begin{aligned}
& \text { Chl } \mathrm{a}=0.999 \times \mathrm{Abs}_{663}-0.0989 \times \mathrm{Abs}_{645} \\
& \mathrm{Chl} \mathrm{b}=-0.328 \times \mathrm{Abs}_{663}+1.77 \times \mathrm{Abs}_{645}
\end{aligned}
$$

The total chlorophyll is the sum of $\mathrm{Chl}$ a and $\mathrm{Chl} \mathrm{b}$. All data are expressed as $\mathrm{mg} 100 \mathrm{~g}^{-1}$ dry weight (mg $\left.100 \mathrm{~g}^{-1} \mathrm{DW}\right)$.

Ascorbic acid ( $\mathrm{mg} \mathrm{g}^{-1} \mathrm{DW}$ ) was determined by the colorimetric method using 2,6 dichlorophenol, $1 \mathrm{~g}$ of fresh tissue, and $\mathrm{HCl}(2 \%)$ as described in Padayatt et al. [53].

Glutathione (mmoL $100 \mathrm{~g}^{-1} \mathrm{DW}$ ) was determined using the method of Xue et al. [54] by means of a 5,5-dithio-bis-2 nitrobenzoic acid (DTNB) reaction. A mix of $0.480 \mathrm{~mL}$ of the extract, $2.2 \mathrm{~mL}$ of sodium dibasic phosphate $\left(\mathrm{Na}_{2} \mathrm{HPO}_{4}\right.$ at $\left.0.32 \mathrm{M}\right)$, and $0.32 \mathrm{~mL}$ of the DTNB dye $(1 \mathrm{mM})$ was placed in a test tube. Then, the mix was vortexed and read on a UV-Vis spectrophotometer (UNICO Spectrophotometer Model UV2150, Dayton, NJ, USA) at $412 \mathrm{~nm}$ using a quartz cell.

Flavonoids (mg $100 \mathrm{~g}^{-1} \mathrm{DW}$ ) were determined by the method of Arvouet-Grand et al. [55]. For the extraction, $100 \mathrm{mg}$ of lyophilized tissue was placed in a test tube where $10 \mathrm{~mL}$ of reagent grade methanol was added and shaken for $30 \mathrm{~s}$ until the mixture was homogenized. The mixture was filtered using No. 1 Whatman paper. For the quantification, $2 \mathrm{~mL}$ of the extract and $2 \mathrm{~mL}$ of methanolic solution of aluminum trichloride $\left(\mathrm{AlCl}_{3}\right) 2 \%$ were added to a test tube and left to rest for $20 \mathrm{~min}$ in the dark. The reading was then taken in a UV-Vis spectrophotometer (UNICO Spectrophotometer Model UV2150, Dayton, NJ, USA) at a wavelength of $415 \mathrm{~nm}$ using a quartz cell.

Phenols ( $\left.\mathrm{mg} \mathrm{g}^{-1} \mathrm{DW}\right)$ were determined with Folin-Ciocalteu reagent as described in Cumplido-Nájera et al. [21]. The sample $(0.2 \mathrm{~g})$ was extracted with $1 \mathrm{~mL}$ of a water:acetone solution (1:1). The mixture was vortexed for $30 \mathrm{~s}$. The tubes were centrifuged (UNICO Spectrophotometer Model UV2150, Dayton, NJ, USA) at $17,500 \times \mathrm{g}$ for $10 \mathrm{~min}$ at $4{ }^{\circ} \mathrm{C}$. In a test tube, $50 \mu \mathrm{L}$ of the supernatant, $200 \mu \mathrm{L}$ of the Folin-Ciocalteu reagent, $500 \mu \mathrm{L}$ of $20 \%$ sodium carbonate $\left(\mathrm{Na}_{2} \mathrm{CO}_{3}\right)$, and $5 \mathrm{~mL}$ of distilled water were added and then vortexed for $30 \mathrm{~s}$. The samples were placed in a water bath at $45^{\circ} \mathrm{C}$ for $30 \mathrm{~min}$. Finally, the reading was taken at an absorbance of $750 \mathrm{~nm}$ using a plastic cell in a UV-Vis spectrophotometer (UNICO Spectrophotometer Model UV2150, Dayton, NJ, USA).

The quantification of total proteins ( $\mathrm{mg} \mathrm{g}^{-1}$ of DW) was performed using Bradford's colorimetric technique [56]. In a microplate, $5 \mu \mathrm{L}$ of the extract and $250 \mu \mathrm{L}$ of Bradford reagent were placed in each 
well. They were incubated for $10 \mathrm{~min}$ at room temperature $\left(26^{\circ} \mathrm{C}\right)$ and then read at a wavelength of $630 \mathrm{~nm}$ on a microplate reader (Allsheng, AMR-100 model, Hangzhou, China).

The antioxidant capacity was determined using DPPH (2,2-diphenyl-1-picrylhydrazyl) radical according to Brand-Williams et al. [57]. Hydrophilic compounds were determined using phosphate buffer for extraction and, for lipophilic compounds, a hexane:acetone solution was used. The total antioxidant capacity was obtained by the sum of the hydrophilic and lipophilic compounds [58]. The antioxidant capacity was expressed as ascorbic acid equivalents $\left(\mathrm{mg} \mathrm{g}^{-1} \mathrm{DW}\right)$

The extract used was the same as that used for total proteins and following the standard techniques. The enzymes evaluated were ascorbate peroxidase (EC 1.11.1.11) [59], glutathione peroxidase (EC 1.11.1.9) [54,60], catalase (EC 1.11.1.6) [61], and phenylalanine ammonia lyase (PAL) (EC 4.3.1.5) [62].

\subsection{Statistical Analysis}

For the evaluation of the agronomic variables, 10 repetitions per treatment were considered and, for the biochemical variables, five repetitions per treatment. A completely randomized design was used, and analysis of variance and Duncan means test $(\alpha=0.05)$ were performed using the InfoStat software (v2018) (https://www.infostat.com.ar).

\section{Conclusions}

The application of carbon nanomaterials in both routes of application (i.e., foliar and drench) modifies the antioxidant defense system of tomato seedlings generally positively. However, for each specific antioxidant compound, the responses were different depending on the type of carbon nanomaterial used (carbon nanotubes or graphene), the route of application (foliar or drench), as well as the doses used.

Additionally, the application of CNMs increased the chlorophyll content regardless of the route of application and, especially, with the application of graphene. The content of antioxidant proteins and enzymes also increased.

The results show that the antioxidant defense system of tomato seedlings can be improved which can potentially increase tolerance against various types of biotic or abiotic stress. In addition, no toxicity was observed for any dose of CNMs used, since there were no negative effects on biomass production.

Author Contributions: Conceptualization, A.J.-M., G.C.-P. and A.B.-M.; methodology and formal analysis, Y.G.-G. and E.R.L.-V.; writing-original draft preparation, Y.G.-G., S.G.-M., A.R.-O. and Á.G.A.-S. review and editing. All authors were responsible for writing, review, and editing.

Funding: This research received no external funding.

Conflicts of Interest: The authors declare no conflict of interest.

$\begin{array}{ll}\text { Abbreviations } \\ \text { CNMs } & \text { carbon-based nanomaterials } \\ \text { CNT } & \text { carbon nanotubes } \\ \text { GP } & \text { graphene } \\ \text { SWCNT } & \text { single-wall carbon nanotubes } \\ \text { MWCNT } & \text { multi-wall carbon nanotubes } \\ \text { DPPH } & \text { 2,2-diphenyl-1-picrylhydrazyl } \\ \text { TAC } & \text { total antioxidant capacity } \\ \text { GSH } & \text { glutathione } \\ \text { APX } & \text { ascorbate peroxidase } \\ \text { GPX } & \text { glutathione peroxidase } \\ \text { CAT } & \text { catalase } \\ \text { PAL } & \text { phenylalanine ammonium lyase }\end{array}$




\section{References}

1. Verma, S.K.; Das, A.K.; Gantait, S.; Kumar, V.; Gurel, E. Applications of carbon nanomaterials in the plant system: A perspective view on the pros and cons. Sci. Total Environ. 2019, 667, 485-499. [CrossRef] [PubMed]

2. Ghorbanpour, M.; Hadian, J. Multi-walled carbon nanotubes stimulate callus induction, secondary metabolites biosynthesis and antioxidant capacity in medicinal plant Satureja khuzestanica grown in vitro. Carbon N. Y. 2015, 94, 749-759. [CrossRef]

3. Dehghani, M.H.; Kamalian, S.; Shayeghi, M.; Yousefi, M.; Heidarinejad, Z.; Agarwal, S.; Gupta, V.K. High-performance removal of diazinon pesticide from water using multi-walled carbon nanotubes. Microchem. J. 2019, 145, 486-491. [CrossRef]

4. $\quad$ Fiyadh, S.S.; AlSaadi, M.A.; Jaafar, W.Z.; AlOmar, M.K.; Fayaed, S.S.; Mohd, N.S.; Hin, L.S.; El-Shafie, A. Review on heavy metal adsorption processes by carbon nanotubes. J. Clean. Prod. 2019, 230, $783-793$. [CrossRef]

5. Patel, A.; Tiwari, S.; Parihar, P.; Singh, R.; Prasad, S.M. Carbon Nanotubes as Plant Growth Regulators: Impacts on Growth, Reproductive System, and Soil Microbial Community. In Nanomaterials in Plants, Algae and Microorganisms; Elsevier: London, UK, 2017; pp. 23-42. [CrossRef]

6. Novoselov, K.S.; Geim, A.K.; Morozov, S.V.; Jiang, D.; Zhang, Y.; Dubonos, S.V.; Grigorieva, I.V.; Firsov, A.A. Electric Field Effect in Atomically Thin Carbon Films. Science 2004, 306, 666-669. [CrossRef] [PubMed]

7. Mukherjee, A.; Majumdar, S.; Servin, A.D.; Pagano, L.; Dhankher, O.P.; White, J.C. Carbon Nanomaterials in Agriculture: A Critical Review. Front. Plant Sci. 2016, 7, 172. [CrossRef]

8. Wang, J.; Jin, X.; Li, C.; Wang, W.; Wu, H.; Guo, S. Graphene and graphene derivatives toughening polymers: Toward high toughness and strength. Chem. Eng. J. 2019, 370, 831-854. [CrossRef]

9. Liu, J.; Cui, L.; Losic, D. Graphene and graphene oxide as new nanocarriers for drug delivery applications. Acta Biomater. 2013, 9, 9243-9257. [CrossRef]

10. Yang, Y.; Asiri, A.M.; Tang, Z.; Du, D.; Lin, Y. Graphene based materials for biomedical applications. Mater. Today 2013, 16, 365-373. [CrossRef]

11. Raphey, V.R.; Henna, T.K.; Nivitha, K.P.; Mufeedha, P.; Sabu, C.; Pramod, K. Advanced biomedical applications of carbon nanotube. Mater. Sci. Eng. C 2019, 100, 616-630. [CrossRef]

12. Ménard-Moyon, C. Applications of Carbon Nanotubes in the Biomedical Field. In Smart Nanoparticles for Biomedicine; Elsevier: London, UK, 2018; pp. 83-101.

13. Andelkovic, I.B.; Kabiri, S.; Tavakkoli, E.; Kirby, J.K.; McLaughlin, M.J.; Losic, D. Graphene oxide-Fe(III) composite containing phosphate - A novel slow release fertilizer for improved agriculture management. J. Clean. Prod. 2018, 185, 97-104. [CrossRef]

14. Wang, Q.; Li, C.; Wang, Y.; Que, X. Phytotoxicity of graphene family nanomaterials and its mechanisms: A review. Front. Chem. 2019, 7, 1-7. [CrossRef] [PubMed]

15. Begum, P.; Ikhtiari, R.; Fugetsu, B. Graphene phytotoxicity in the seedling stage of cabbage, tomato, red spinach, and lettuce. Carbon N. Y. 2011, 49, 3907-3919. [CrossRef]

16. Begum, P.; Ikhtiari, R.; Fugetsu, B. Potential Impact of Multi-Walled Carbon Nanotubes Exposure to the Seedling Stage of Selected Plant Species. Nanomaterials 2014, 4, 203-221. [CrossRef]

17. Hatami, M.; Hadian, J.; Ghorbanpour, M. Mechanisms underlying toxicity and stimulatory role of single-walled carbon nanotubes in Hyoscyamus niger during drought stress simulated by polyethylene glycol. J. Hazard. Mater. 2017, 324, 306-320. [CrossRef]

18. Flores, P.; Sánchez, E.; Fenoll, J.; Hellín, P. Genotypic variability of carotenoids in traditional tomato cultivars. Food Res. Int. 2017, 100, 510-516. [CrossRef]

19. Susič, N.; Žibrat, U.; Širca, S.; Strajnar, P.; Razinger, J.; Knapič, M.; Vončina, A.; Urek, G.; Gerič Stare, B. Discrimination between abiotic and biotic drought stress in tomatoes using hyperspectral imaging. Sens. Actuators B Chem. 2018, 273, 842-852. [CrossRef]

20. Juárez-Maldonado, A.; Ortega-Ortiz, H.; González-Morales, S.; Morelos-Moreno, Á.; Cabrera-de la Fuente, M.; Sandoval-Rangel, A.; Cadenas-Pliego, G.; Benavides-Mendoza, A. Nanoparticles and Nanomaterials as Plant Biostimulants. Int. J. Mol. Sci. 2019, 20, 162. [CrossRef]

21. Cumplido-Nájera, C.F.; González-Morales, S.; Ortega-Ortíz, H.; Cadenas-Pliego, G.; Benavides-Mendoza, A.; Juárez-Maldonado, A. The application of copper nanoparticles and potassium silicate stimulate the tolerance to Clavibacter michiganensis in tomato plants. Sci. Hortic. 2019, 245, 82-89. [CrossRef] 
22. Tripathi, S.; Sonkar, S.K.; Sarkar, S. Growth stimulation of gram (Cicer arietinum) plant by water soluble carbon nanotubes. Nanoscale 2011, 3, 1176. [CrossRef]

23. Cheng, F.; Liu, Y.-F.; Lu, G.-Y.; Zhang, X.-K.; Xie, L.-L.; Yuan, C.-F.; Xu, B.-B. Graphene oxide modulates root growth of Brassica napus L. and regulates ABA and IAA concentration. J. Plant Physiol. 2016, 193, 57-63. [CrossRef] [PubMed]

24. Khodakovskaya, M.V.; de Silva, K.; Biris, A.S.; Dervishi, E.; Villagarcia, H. Carbon Nanotubes Induce Growth Enhancement of Tobacco Cells. ACS Nano 2012, 6, 2128-2135. [CrossRef] [PubMed]

25. Rong, H.; Wang, C.; Yu, X.; Fan, J.; Jiang, P.; Wang, Y.; Gan, X.; Wang, Y. Carboxylated multi-walled carbon nanotubes exacerbated oxidative damage in roots of Vicia faba L. seedlings under combined stress of lead and cadmium. Ecotoxicol. Environ. Saf. 2018, 161, 616-623. [CrossRef] [PubMed]

26. Joshi, A.; Kaur, S.; Dharamvir, K.; Nayyar, H.; Verma, G. Multi-walled carbon nanotubes applied through seed-priming influence early germination, root hair, growth and yield of bread wheat (Triticum aestivum L.). J. Sci. Food Agric. 2018. [CrossRef] [PubMed]

27. Komenda, J.; Sobotka, R. Chlorophyll-binding subunits of photosystem I and II: Biosynthesis, chlorophyll incorporation and assembly. In Advances in Botanical Research; Elsevier: London, UK, 2019; Volume 91, pp. 195-223.

28. Fernández-León, M.F.; Lozano, M.; Ayuso, M.C.; Fernández-León, A.M.; González-Gómez, D. Fast and accurate alternative UV-chemometric method for the determination of chlorophyll A and B in broccoli (Brassica oleracea Italica) and cabbage (Brassica oleracea Sabauda) plants. J. Food Compos. Anal. 2010, 23, 809-813. [CrossRef]

29. Younes, N.A.; Dawood, M.F.A.; Wardany, A.A. Biosafety assessment of graphene nanosheets on leaf ultrastructure, physiological and yield traits of Capsicum annum L. and Solanum melongena L. Chemosphere 2019, 228, 318-327. [CrossRef]

30. Chichiriccò, G.; Poma, A. Penetration and Toxicity of Nanomaterials in Higher Plants. Nanomaterials 2015, 5, 851-873. [CrossRef]

31. Giraldo, J.P.; Landry, M.P.; Faltermeier, S.M.; McNicholas, T.P.; Iverson, N.M.; Boghossian, A.A.; Reuel, N.F.; Hilmer, A.J.; Sen, F.; Brew, J.A.; et al. Plant nanobionics approach to augment photosynthesis and biochemical sensing. Nat. Mater. 2014, 13, 400-408. [CrossRef]

32. Siddiqui, Z.A.; Parveen, A.; Ahmad, L.; Hashem, A. Effects of graphene oxide and zinc oxide nanoparticles on growth, chlorophyll, carotenoids, proline contents and diseases of carrot. Sci. Hortic. 2019, 249, 374-382. [CrossRef]

33. Kwon, D.H.; Lee, H.; Park, C.; Hong, S.-H.; Hong, S.H.; Kim, G.-Y.; Cha, H.-J.; Kim, S.; Kim, H.-S.; Hwang, H.-J.; et al. Glutathione Induced Immune-Stimulatory Activity by Promoting M1-Like Macrophages Polarization via Potential ROS Scavenging Capacity. Antioxidants 2019, 8, 413. [CrossRef]

34. Sharma, S.; Sehrawat, A.; Deswal, R. Asada-Halliwell pathway maintains redox status in Dioscorea alata tuber which helps in germination. Plant. Sci. 2016, 250, 20-29. [CrossRef] [PubMed]

35. Hasanuzzaman, M.; Bhuyan, M.H.M.B.; Anee, T.I.; Parvin, K.; Nahar, K.; Mahmud, J.A.; Fujita, M. Regulation of Ascorbate-Glutathione Pathway in Mitigating Oxidative Damage in Plants under Abiotic Stress. Antioxidants 2019, 8, 384. [CrossRef] [PubMed]

36. Akram, N.A.; Shafiq, F.; Ashraf, M. Ascorbic Acid-A Potential Oxidant Scavenger and Its Role in Plant Development and Abiotic Stress Tolerance. Front. Plant. Sci. 2017, 8, 613. [CrossRef] [PubMed]

37. Weber, F.; Passon, M. Characterization and Quantification of Polyphenols in Fruits. Polyphen. Plants 2019, 111-121. [CrossRef]

38. Li, Q.; Yang, S.; Li, Y.; Xue, X.; Huang, Y.; Luo, H.; Zhang, Y.; Lu, Z.; Li, Q.; Yang, S.; et al. Comparative Evaluation of Soluble and Insoluble-Bound Phenolics and Antioxidant Activity of Two Chinese Mistletoes. Molecules 2018, 23, 359. [CrossRef]

39. Zhou, J.; Ma, Y.; Jia, Y.; Pang, M.; Cheng, G.; Cai, S. Phenolic profiles, antioxidant activities and cytoprotective effects of different phenolic fractions from oil palm (Elaeis guineensis Jacq.) fruits treated by ultra-high pressure. Food Chem. 2019, 288, 68-77. [CrossRef]

40. Shahidi, F.; Yeo, J.; Shahidi, F.; Yeo, J. Insoluble-Bound Phenolics in Food. Molecules 2016, 21, 1216. [CrossRef]

41. Cheynier, V.; Comte, G.; Davies, K.M.; Lattanzio, V.; Martens, S. Plant phenolics: Recent advances on their biosynthesis, genetics, and ecophysiology. Plant Physiol. Biochem. 2013, 72, 1-20. [CrossRef] 
42. Vochita, G.; Oprica, L.; Gherghel, D.; Mihai, C.T.; Boukherroub, R.; Lobiuc, A. Graphene oxide effects in early ontogenetic stages of Triticum aestivum L. seedlings. Ecotoxicol. Environ. Saf. 2019, 181, 345-352. [CrossRef]

43. Bell, I.R.; Ives, J.A.; Jonas, W.B. Nonlinear effects of nanoparticles: Biological variability from hormetic doses, small particle sizes, and dynamic adaptive interactions. Dose-Response 2014, 12, 202-232. [CrossRef]

44. Rai, P.K.; Kumar, V.; Lee, S.; Raza, N.; Kim, K.-H.; Ok, Y.S.; Tsang, D.C.W. Nanoparticle-plant interaction: Implications in energy, environment, and agriculture. Environ. Int. 2018, 119, 1-19. [CrossRef] [PubMed]

45. Mohanta, D.; Patnaik, S.; Sood, S.; Das, N. Carbon nanotubes: Evaluation of toxicity at biointerfaces. J. Pharm. Anal. 2019. [CrossRef]

46. Jordan, J.T.; Singh, K.P.; Cañas-carrell, J.E. Carbon-Based Nanomaterials Elicit Changes in Physiology, Gene Expression, and Epigenetics in Exposed Plants: A Review. Curr. Opin. Environ. Sci. Heal. 2018. [CrossRef]

47. Ozyigit, I.I.; Filiz, E.; Vatansever, R.; Kurtoglu, K.Y.; Koc, I.; Öztürk, M.X.; Anjum, N.A. Identification and Comparative Analysis of H2O2-Scavenging Enzymes (Ascorbate Peroxidase and Glutathione Peroxidase) in Selected Plants Employing Bioinformatics Approaches. Front. Plant. Sci. 2016, 7, 301. [CrossRef] [PubMed]

48. Anjum, N.A.; Singh, N.; Singh, M.K.; Sayeed, I.; Duarte, A.C.; Pereira, E.; Ahmad, I. Single-bilayer graphene oxide sheet impacts and underlying potential mechanism assessment in germinating faba bean (Vicia faba L.). Sci. Total Environ. 2014, 472, 834-841. [CrossRef] [PubMed]

49. Huang, J.; Gu, M.; Lai, Z.; Fan, B.; Shi, K.; Zhou, Y.-H.; Yu, J.-Q.; Chen, Z. Functional Analysis of the Arabidopsis PAL Gene Family in Plant Growth, Development, and Response to Environmental Stress. Plant. Physiol. 2010, 153, 1526-1538. [CrossRef]

50. Astaneh, R.K.; Bolandnazar, S.; Nahandi, F.Z.; Oustan, S. Effect of selenium application on phenylalanine ammonia-lyase (PAL) activity, phenol leakage and total phenolic content in garlic (Allium sativum L.) under $\mathrm{NaCl}$ stress. Inf. Process. Agric. 2018, 5, 339-344. [CrossRef]

51. Steiner, A.A. A universal method for preparing nutrient solutions of a certain desired composition. Plant. Soil 1961, 15, 134-154. [CrossRef]

52. Nagata, M.; Yamashita, I. Simple Method for Simultaneous Determination of Chlorophyll and Carotenoids in Tomato Fruit. J. Jpn. Soc. Food Sci. Technol. Shokuhin Kagaku Kogaku Kaishi 1992, 39, 925-928. [CrossRef]

53. Levine, M.; Katz, A.; Padayatty, S.J.; Wang, Y.; Eck, P.; Kwon, O.; Chen, S.; Lee, J.H.; Vitamin, C. Encyclopedia of Dietary Supplements; CRC Press: Boca Raton, FL, USA, 2004; pp. 745-755. ISBN 9781482204056.

54. Xue, T.; Hartikainen, H.; Piironen, V. Antioxidative and growth-promoting effect of selenium on senescing lettuce. Plant. Soil 2001, 237, 55-61. [CrossRef]

55. Arvouet-Grand, A.; Vennat, B.; Pourrat, A.; Legret, P. Standardization of propolis extract and identification of principal constituents. J. Pharm. Belg. 1994, 49, 462-468. [PubMed]

56. Bradford, M.M. A rapid and sensitive method for the quantitation of microgram quantities of protein utilizing the principle of protein-dye binding. Anal. Biochem. 1976, 72, 248-254. [CrossRef]

57. Brand-Williams, W.; Cuvelier, M.E.; Berset, C. Use of a Free Radical Method to Evaluate Antioxidant Activity. Food Sci. Technol. 1995, 28, 25-30. [CrossRef]

58. Arnao, M.B.; Cano, A.; Acosta, M. The hydrophilic and lipophilic contribution to total antioxidant activity. Food Chem. 2001, 73, 239-244. [CrossRef]

59. Nakano, Y.; Asada, K. Purification of ascorbate peroxidase in spinach chloroplasts; its inactivation in ascorbate-depleted medium and reactivation by monodehydroascorbate radical. Plant. Cell Physiol. 1987, 28, 131-140. [CrossRef]

60. Flohé, L.; Günzler, W.A. Assays of glutathione peroxidase. Methods Enzymol. 1984, 105, 114-120. [CrossRef]

61. Dhindsa, R.S.; Plumb-dhindsa, P.; Thorpe, T.A. Leaf senescence: Correlated with increased levels of membrane permeability and lipid peroxidation, and decreased levels of superoxide dismutase and catalase. J. Exp. Bot. 1981, 32, 93-101. [CrossRef]

62. Sykłowska-Baranek, K.; Pietrosiuk, A.; Naliwajski, M.R.; Kawiak, A.; Jeziorek, M.; Wyderska, S.; Łojkowska, E.; Chinou, I. Effect of l-phenylalanine on PAL activity and production of naphthoquinone pigments in suspension cultures of Arnebia euchroma (Royle) Johnst. Vitr. Cell. Dev. Biol. Plant. 2012, 48, 555-564. [CrossRef]

(C) 2019 by the authors. Licensee MDPI, Basel, Switzerland. This article is an open access article distributed under the terms and conditions of the Creative Commons Attribution (CC BY) license (http://creativecommons.org/licenses/by/4.0/). 